\title{
Induction of uncoupling protein-2 mRNA by triiodothyronine in rat liver
}

\author{
Radka Bolehovská ${ }^{1,2}$, Monika Pospíšilová2 ${ }^{2}$ David Rychtrmoc ${ }^{2}$, Lenka Hubálková2, \\ Zuzana Červinková ${ }^{2}$ \\ ${ }^{1}$ Department of Clinical Biochemistry and Diagnostics, Charles University, Faculty of Medicine and University \\ Hospital in Hradec Králové, Czech Republic \\ ${ }^{2}$ Department of Physiology, Faculty of Medicine of Charles University \\ in Hradec Králové, Czech Republic
}

Received December 22, 2010

Accepted February 14, 2012

\begin{abstract}
Uncoupling protein-2, discovered in 1997, is the first described homologue of uncoupling protein-1. Uncoupling proteins increase the permeability of inner mitochondrial membrane for protons, decrease the efficiency of energy conversion, inhibit the ATP synthesis and stimulate energy release in form of heat. Uncoupling proteins also increase the substrate oxidation and reduce production of reactive oxygen species in mitochondria. The present study was conducted to assess the effects of acute treatment with triiodothyronine on uncoupling protein-2 mRNA levels in Wistar rats. Intraperitoneal injection of one dose of triiodothyronine $(200 \mu \mathrm{g} / \mathrm{kg}$ rat body weight) increased mRNA expression of uncoupling protein-2 in liver tissue almost 2 -fold after $12 \mathrm{~h}$. Concentrations of total triiodothyronine and free triiodothyronine in serum were increased 122-fold and 76-fold, respectively. These results suggest that gene coding uncoupling protein-2 is gene inducible in the liver shortly after single administration of $\mathrm{T}_{3}$. Data about the kinetics of $\mathrm{T}_{3}$ mediated induction of UCP-2 mRNA during the first $24 \mathrm{~h}$ after treatment were not available in literature so far and therefore constitute our priority findings.
\end{abstract}

Expression kinetics of UCP-2 mRNA, thyroid hormones, mitochondrial glycerophosphate dehydrogenase

Uncoupling proteins (UCPs) belong to the great family of mitochondrial anion carriers localized in inner membrane of mitochondria. Uncoupling proteins mediate back flow of protons via inner mitochondrial membrane, thereby decreasing electrochemical proton gradient normally used for ATP synthesis from ADP and inorganic phosphate by ATPsynthase. In this case the ATP synthesis is decreased and energy is dissipated in form of heat. Current data indicate that the UCPs play a potentially important role as determinants of metabolic efficiency in mammals. Uncoupling proteins also increase substrate oxidation and lower formation of reactive oxygen species (ROS) in mitochondria (Ricquier and Bouillaud 2000).

UCP-2 protein is expressed in many tissues, including tissues rich in macrophages, white and brown adipose tissue, skeletal and heart muscle, kidney, brain and others (Fleury and Sanchis 1999). Hepatocytes of adult rat liver do not express UCP-2, in contrast to foetal hepatocytes (Hodný et al. 1998) and non-parenchymal liver cells, especially Kupffer cells (Fleury and Sanchis 1999). Absence of UCP-2 expression is reversible and UCP-2 mRNA level can be increased manifold in a short period of time. UCP-2 expression in hepatocytes can be induced by conditions leading to their dedifferentiation, e.g. during liver regeneration after partial hepatectomy (Lee et al. 1999) or after lipopolysaccharide administration via tumor necrosis factor $\alpha$ signalling (Cortez-Pinto et al. 1998). Apart from the well-known regulation of UCP-1 by triiodothyronine $\left(\mathrm{T}_{3}\right)$, it has been recently reported that $\mathrm{T}_{3}$ stimulates UCP-2 mRNA expression in several organs (Lanni et al. 1997).

Only few studies of possible induction of UCP-2 mRNA expression in liver tissue during Address for correspondence:

Radka Bolehovská

Institute of Clinical Biochemistry and Diagnostics

Charles University in Prague, Faculty of Medicine and University

Hospital in Hradec Králové

Sokolská 581, 50005 Hradec Králové, Czech Republic

Phone: +420495833894

Fax: +420495832003

E-mail: bolehrad@fnhk.cz

http://www.vfu.cz/acta-vet/actavet.htm 
$24 \mathrm{~h}$ after application of thyroid hormones have been published so far. Thyroid hormones (THs) play important roles in the differentiation, growth and metabolism mainly in the liver tissue (Červinková et al. 1984). The influence of THs on the metabolic rate and oxygen consumption of nearly all tissues is their most important effect in adults. The effect attributed to $\mathrm{T}_{3}$ is transcriptional and post-transcriptional regulation of the target genes encoding components of mitochondrial energy-transducing apparatus (Lanni et al. 1997). The aim of this study was to investigate the expression of mRNA for UCP-2 in rat liver tissue induced by $\mathrm{T}_{3}$ in different time periods after its administration.

\section{Materials and Methods}

Animals and treatments

Mature male Wistar rats (BioTest, Czech Republic) with an initial body mass of $230 \pm 10 \mathrm{~g}$ were housed at $23 \pm 1{ }^{\circ} \mathrm{C}$ under standard conditions. The animals had free access to standard laboratory rat chow (ST-1, Velaz) and tap water. All animals received care according to the guidelines set by the institutional Animal Use and Care Committee of the Charles University in Prague, Faculty of Medicine in Hradec Králové.

Four control rats were sacrificed under ether anaesthesia by exsanguination from abdominal aorta $3 \mathrm{~h}$ after the administration of one dose of saline. Twenty experimental rats were treated with a single dose of $\mathrm{T}_{3}$ (intraperitoneal injection of $200 \mu \mathrm{g} \mathrm{T} / \mathrm{kg}$ body weight). These rats were divided into five groups (4 rats in a group) according to time period $\left(1,3,6,12\right.$ and 24 hours) from $\mathrm{T}_{3}$ administration to sacrifice. Whole livers (weights were 9.80 $\pm 1.05 \mathrm{~g}$ ) were surgically removed and immediately frozen in liquid nitrogen, then stored at $-70{ }^{\circ} \mathrm{C}$ until RNA extraction.

Similar design of experiment was used in a group of rats receiving three doses of saline (control group) and three doses of $\mathrm{T}_{3}$ (i. p. administration of $200 \mu \mathrm{g} \mathrm{T} / \mathrm{kg}$ body weight - experimental group), administered at $24 \mathrm{~h}$ intervals in both groups. The rats were sacrificed $1,3,6,12$ and $24 \mathrm{~h}$ after the last dose of saline or $\mathrm{T}_{3}$.

RNA isolation

RNA was extracted from liver tissue by the commercial reagent RNA Blue (Top-Bio, Czech Republic). The principle of this method was described by Chomczynski and Sacchi (1987). The concentrations of RNA were determined by spectrophotometry at $260 \mathrm{~nm}$. The purities of RNA measured as ratio of absorbance at $260 \mathrm{~nm}$ to $280 \mathrm{~nm}$ were between 1.9 and 2.1 . The RNA samples were stored at $-70{ }^{\circ} \mathrm{C}$.

\section{Real-time RT PCR}

Expression of UCP-2 RNA was quantified by real-time RT PCR. Synthesis of cDNA was performed with Moloney murine leukaemia virus reverse transcriptase (M-MLV, Top-Bio) and oligo(dT) primer with the sequence 5'TTTTTTTTTTTTTTTVN-3' (Generi Biotech, Czech Republic) according to the enzyme manufacturer protocol. Thermal profile of reverse transcription was $37{ }^{\circ} \mathrm{C}$ for $60 \mathrm{~min}$., $94{ }^{\circ} \mathrm{C}$ for $5 \mathrm{~min}$. and $4{ }^{\circ} \mathrm{C}$ for $2 \mathrm{~min}$. The completion of the cDNA synthesis reaction was confirmed by classic end-point PCR amplification of housekeeping gene glyceraldehyde-3-phosphate dehydrogenase (GADPH) as described elsewhere (Saito et al. 2000).

Real-time PCR amplification of cDNA was performed with ABI Prism 7900HT instrument. To assure high-level of specificity, pair of oligonucleotide primers and dual-labelled probe labelled with BHQ-FAM were used as a detection system. New set of probe and primers for quantification of rat UCP-2 mRNA was designed and synthetized by biotechnology company Generi Biotech s.r.o. - forward primer 5'AAGACCATTGCACGAGAGGA3', reverse primer 5'GCAAGGGAGGTCGTCTGTC3' and probe 5'CCCAATGTTGCCCGAAATGCC3'. Rat UCP-2 amplicon spans $159 \mathrm{bp}$. We used surfeit-1 (SURF-1) gene as a reference gene for normalization. Commercial mix of primers and dual-labelled (BHQ-FAM) probe (Generi Biotech) were used. Primers were designed to avoid amplification of genomic DNA.

The reaction mixture in a final volume $20 \mu \mathrm{l}$ contained $4 \mu \mathrm{l}$ cDNA (without purification), primers in final concentration $0.2 \mu \mathrm{mol} \cdot 1^{-1}$, probe in final concentration $0.1 \mu \mathrm{mol} \cdot 1^{-1}$ and $10 \mu \mathrm{l}$ TaqMan Universal Master Mix (final concentration $1 \times$, Applied Biosystems, USA) according to the manufacturer. Thermocycling conditions were following: $50^{\circ} \mathrm{C}$ for $2 \mathrm{~min}, 95^{\circ} \mathrm{C}$ for $10 \mathrm{~min}$ and 55 cycles of elongation $\left(95^{\circ} \mathrm{C}\right.$ for $15 \mathrm{~s}, 60^{\circ} \mathrm{C}$ for $1 \mathrm{~min}$ with data acquisition of FAM channel). Each sample was used in 2 technical replicates. Threshold and baseline were set manually to get maximum value of coefficient $\mathrm{R}$ (threshold value was 0.05 and baseline was adjusted in the range 3 to 15). Relative quantification was performed using of $2^{-\Delta \Delta \mathrm{Ct}}$ method corrected for efficiency of amplification (Livak and Schmittgen 2001).

Measurement of serum total $\mathrm{T}_{3}$, free $\mathrm{T}_{3}$

Serum concentrations of total $\mathrm{T}_{3}^{3}\left(\mathrm{tT}_{3}\right)$ and free $\mathrm{T}_{3}\left(\mathrm{fT}_{3}\right)$ were measured with the commercial kits on DPC IMMULITE 2000 Instrument ( $\mathrm{tT}_{3}$ was measured by a solid-phase, competitive chemiluminiscent enzyme immunoassay, $\mathrm{fT}_{3}$ was measured by a competitive analog-based immunoassay). The upper limit for $\mathrm{tT}_{3}$ detection was $10 \mathrm{nmol} \cdot 1^{-1}$ and for $\mathrm{fT}_{3}$ it was $50 \mathrm{pmol} \cdot 1^{-1}$, samples with higher analyte concentrations were diluted accordingly. 
Isolation of mitochondria and enzyme activity measurement

Liver mitochondria were isolated by differential centrifugation in $0.25 \mathrm{~mol} \cdot \cdot^{-1}$ sucrose, $10 \mathrm{mmol} \cdot \mathrm{l}^{-1} \mathrm{Tris}-\mathrm{HCl}$, $1 \mathrm{mmol} \cdot \mathrm{r}^{-1}$ EDTA, $\mathrm{pH} 7.4$ as described by Schneider and Hogeboom (1950). Activities of mitochondrial glycerophosphate dehydrogenase $(\mathrm{mGPDH})$ and succinate dehydrogenase $(\mathrm{SDH})$ were measured using 2,6-dichlorophenol indophenol (DCPIP), as electron acceptor, in a medium containing $50 \mathrm{mmol} \cdot \mathrm{l}^{-1} \mathrm{KCl}, 10$ mmol $\cdot{ }^{-1}$ Tris, $1 \mathrm{mmol} \cdot \cdot^{-1}$ EDTA, $1 \mathrm{mmol} \cdot \cdot^{-1} \mathrm{KCN}$. Prior to measurement $10 \mu \mathrm{BSA}\left(100 \mathrm{mg} \cdot \mathrm{ml}^{-1}\right), 10 \mu \mathrm{KCN}(100$ $\left.\mathrm{mmol} \cdot \mathrm{l}^{-1}\right), 10 \mu \mathrm{l}$ DCPIP $\left(10 \mathrm{mmol} \cdot \mathrm{l}^{-1}\right), 10 \mu \mathrm{l}$ of isolated liver mitochondria were added. The reaction was started by $10 \mu \mathrm{l} \cdot \mathrm{ml}^{-1}$ of glycerophosphate or succinate $\left(1 \mathrm{~mol} \cdot \mathrm{l}^{-1}\right)$ and changes of absorbance at $610 \mathrm{~nm}$ were measured. Levels of mGPDH and SDH activity were determined in liver mitochondria isolated from rats sacrificed 24 and $72 \mathrm{~h}$ after the third dose of $\mathrm{T}_{3}$. That enabled to detect the maximum of enzyme activities followed by their drop.

\section{Statistical analysis}

Statistics were done using MedCalc software (MedCalc Software, Belgium). The values of UCP-2 mRNA expression were normalized to values of SURF-1 mRNA expression for each sample and then the calculated data were averaged per experimental group and the standard deviations were calculated. The significance of differences between the experimental group and the control group was obtained by unpaired two-tailed Student's $t$-test. $P$ value lower than 0.05 , was considered significant.

\section{Results}

As shown in Figs 1 and 2, concentrations of $\mathrm{tT}_{3}$ and $\mathrm{fT}_{3}$ increased very quickly during the first $3 \mathrm{~h}$ with the maximum concentration at the third hour: 111-fold increased $\mathrm{tT}_{3}$ concentration compared to control group $(P<0.001)$ and 89 -fold for $\mathrm{fT}_{3}$ values $(P<0.001)$. Both concentrations then gradually decreased, and after $24 \mathrm{~h}$ the $\mathrm{tT}_{3}$ and $\mathrm{fT}_{3}$ values were still elevated compared to the control group. Both parameters had similar kinetics with the highest concentration rise during the first hour and maximum at the third hour followed by a relatively fast decrease.

To determine the time course of UCP-2 induction, analysis was performed at the same time points after $\mathrm{T}_{3}$ treatment as in $\mathrm{tT}_{3}$ and $\mathrm{fT}_{3}$ measurement. Low concentration of UCP2 mRNA was detected in liver tissue before $\mathrm{T}_{3}$ treatment. UCP-2 mRNA expression did not change significantly during the first $6 \mathrm{~h}$ after single dose of $\mathrm{T}_{3}$ Maximal, significant increase $(P<0.01)$ was detected $12 \mathrm{~h}$ after $\mathrm{T}_{3}$ administration with almost 2 -fold increase vs. control group of rats. After the following $12 \mathrm{~h}$, the UCP-2 mRNA dropped to

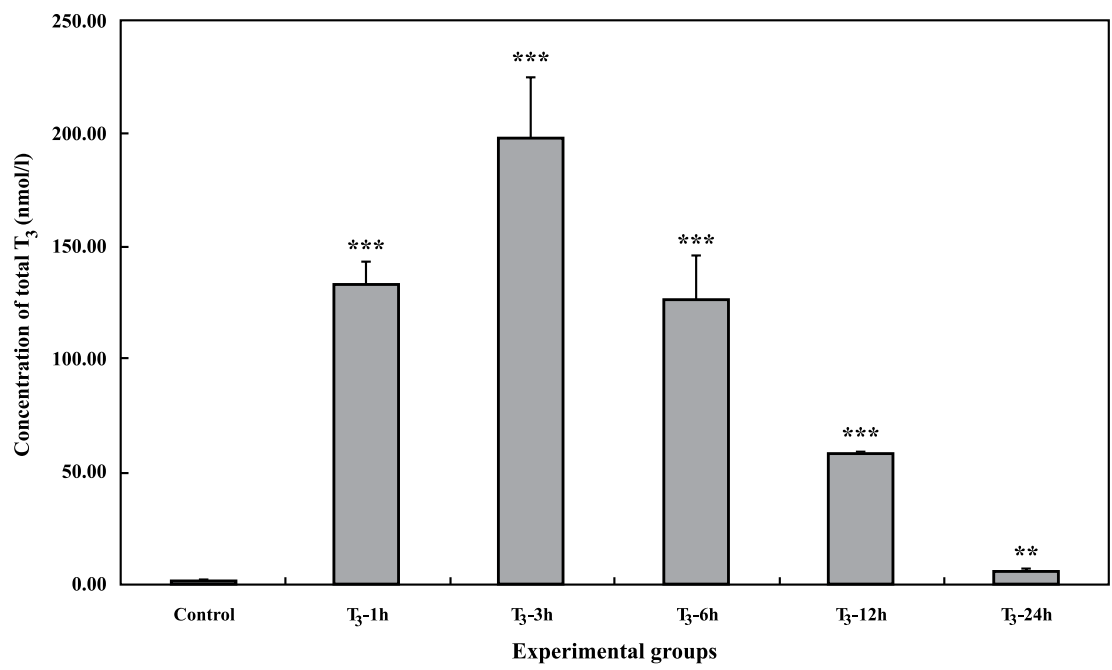

Fig. 1. Serum concentration of total triiodothyronine $\left(\mathrm{tT}_{3}\right)$ in control group and groups of rats treated with one dose of $\mathrm{T}_{3}$ during $24 \mathrm{~h}$. $* * * P<0.001 \mathrm{vs}$. control group, ${ }^{* *} P<0.01 \mathrm{vs}$. control group 


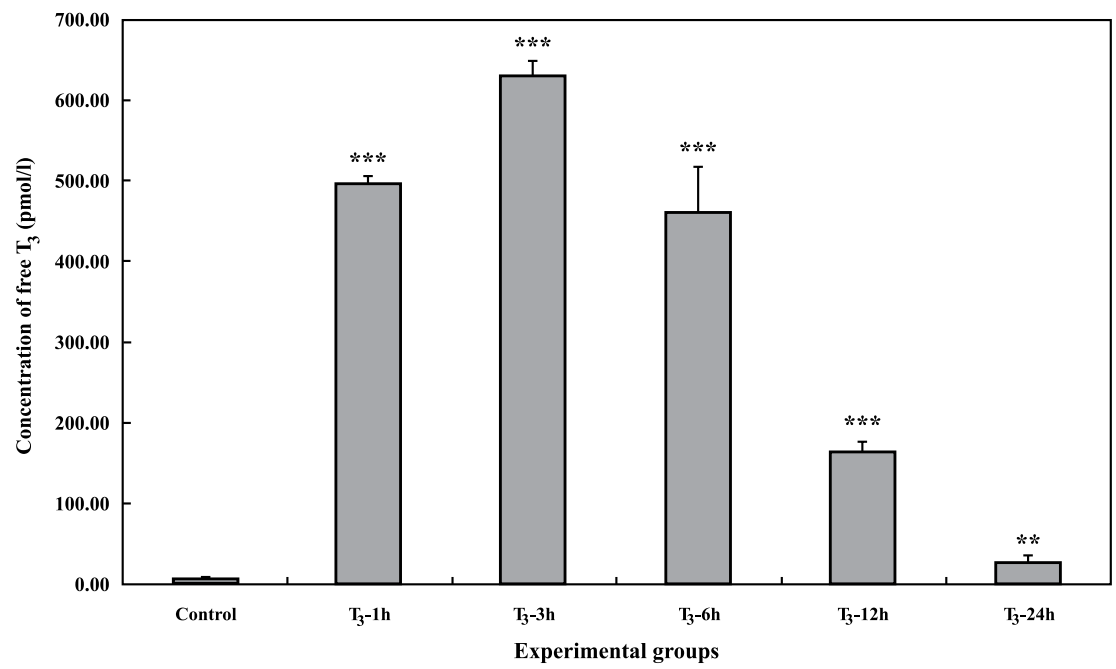

Fig. 2. Serum concentration of free triiodothyronine ( $\left.\mathrm{fT}_{3}\right)$ in control group and groups of rats treated for $1-24 \mathrm{~h}$ with one dose of $\mathrm{T}_{3}{ }^{* * *} P<0.001$ vs. control group, ${ }^{* *} P<0.01$ vs. control group.

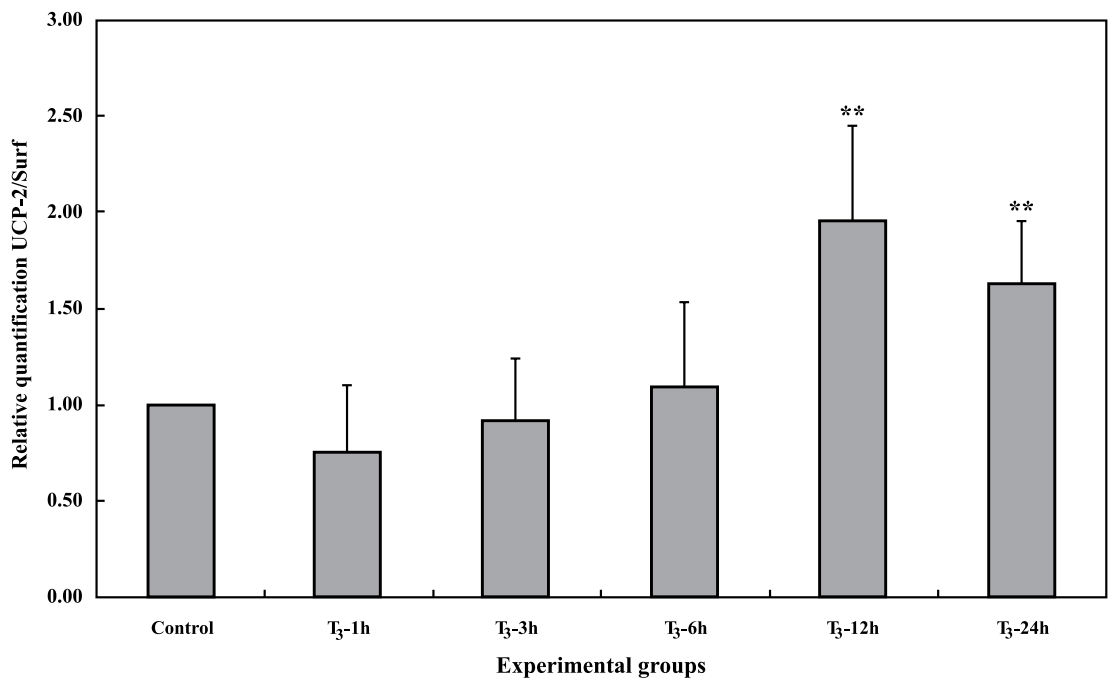

Fig. 3. The effect of single dose of $\mathrm{T}_{3}$ on UCP-2 mRNA expression in liver tissue. UCP-2 mRNA was quantified by using relative quantification method with normalization to reference gene surfeit-1. ${ }^{* *} P<0.01$ vs. control group.

1.63 -fold vs. controls, this reduction was significant, too $(P<0.01)$. Just a moderate decrease about 0.32 -fold was detected at $24^{\text {th }} \mathrm{h}$ after $\mathrm{T}_{3}$ application compared to $12^{\text {th }} \mathrm{h}$. It means that the UCP-2 mRNA expression decrease to the initial concentration is very slow. Maximum expression of the UCP-2 mRNA was delayed for $9 \mathrm{~h}$ compared to the $\mathrm{T}_{3}$ and $\mathrm{fT}_{3}$ concentrations in serum (maximum concentrations at $3 \mathrm{~h}$ ). Fig. 3 shows the time course of UCP-2 induction after the $\mathrm{T}_{3}$ treatment. All data are summarized in Table 1 with their 
Table 1. Changes in uncoupling protein- 2 mRNA expression and in concentration of total $T_{3}\left(t T_{3}\right)$ and free $T_{3}\left(\mathrm{fT}_{3}\right)$ after treatment with single dose of triiodothyronine

\begin{tabular}{llccc}
\hline Group of rats & $\mathrm{n}$ & $\mathrm{UCP}-2 \mathrm{mRNA}^{1}$ & $\mathrm{tT}_{3}(\mathrm{nmol} / \mathrm{l})^{2}$ & $\mathrm{fT}_{3}(\mathrm{pmol} / 1)^{2}$ \\
\hline Controls & 4 & 1.0 & $1.78 \pm 0.36$ & $7.08 \pm 2.04$ \\
$\mathrm{~T}_{3}$-treated after 1h & 4 & $0.75 \pm 0.35$ & $133.00 \pm 9.90 * * *$ & $496.00 \pm 8.49 * * *$ \\
$\mathrm{~T}_{3}$-treated after 3h & 4 & $0.92 \pm 0.32$ & $198.00 \pm 26.87 * * *$ & $631.00 \pm 16.97 * * *$ \\
$\mathrm{~T}_{3}$-treated after 6h & 4 & $1.09 \pm 0.43$ & $126.00 \pm 19.80 * * *$ & $460.00 \pm 57.98 * * *$ \\
$\mathrm{~T}_{3}$-treated after 12h & 4 & $1.95 \pm 0.49 * *$ & $57.95 \pm 1.06 * * *$ & $163.50 \pm 14.85 * * *$ \\
$\mathrm{~T}_{3}$-treated after 24h & 4 & $1.63 \pm 0.33 * *$ & $5.70 \pm 1.64 * *$ & $27.18 \pm 9.36 * *$ \\
\hline
\end{tabular}

${ }^{1}$ Values are calculated as mean \pm standard deviations (SD) of UCP-2 mRNA relative quantity (normalization to surfeit-1 mRNA) compared with control group of rats. Control group received one dose of physiological saline. A dose of $200 \mu \mathrm{g} \mathrm{T}_{3} / \mathrm{kg}$ rat body weight was injected intraperitoneally to $\mathrm{T}_{3}$ groups of rats.

${ }^{2}$ Values are calculated as mean $\pm \mathrm{SD}$ of $\mathrm{tT}_{3}$ and free $\mathrm{T}_{3}$ concentrations

** $P<0.01$ vs. the control group; *** $P<0.001 \mathrm{vs.} \mathrm{the} \mathrm{control} \mathrm{group}$

standard deviations and significance. No significant induction of UCP-2 gene expression was observed during the follow-up of the UCP-2 mRNA levels after the administration of three doses of $200 \mu \mathrm{g} \mathrm{T} / \mathrm{kg}$ rat body weight (data not shown).

We have also studied the activity of two enzymes of respiratory chain that may be affected by the application of $\mathrm{T}_{3}$, namely mitochondrial glycerophosphate dehydrogenase and succinate dehydrogenase. In addition mGPDH may be a source of hydrogene peroxide, a source of reactive oxygen radicals inside mitochondria, whose generation is reduced by UCP-2 protein. During the follow-up of mGPDH activity in mitochondria of rats treated with 3 doses of $\mathrm{T}_{3}$ a significant increase compared to controls was observed. This increase reached its maximum $18.28 \mathrm{mGPDH}$ activity/mg of protein at $24 \mathrm{~h}$ after the last $\mathrm{T}_{3}$ administration. Compared with the control liver mitochondria, the increase of mGPDH activity was 3.66 -fold $(P<0.001)$ followed by a very slow decrease within the further $48 \mathrm{~h}$. As late as $72 \mathrm{~h}$ after the last $\mathrm{T}_{3}$ administration the enzyme activity was still 3.51 -fold higher (17.53 $\mathrm{mGPDH}$ activity/mg of protein; $P<0.001$ ). As to SDH only a minimal increase of the enzyme activity was detected in rats treated with 3 doses of $\mathrm{T}_{3}: 1.27$-fold increase at $24 \mathrm{~h}$ after the last $\mathrm{T}_{3}$ administration $(P<0.01)$ and 1.28 -fold increase at $72 \mathrm{~h}(P<0.05)$.

The correlation between increases of mGPDH activity (eventually SDH activity) and the total and free $T_{3}$ concentrations was determined in the control group and in groups of rats treated with 3 doses of $\mathrm{T}_{3}$. These rats were sacrificed at the same time intervals as in enzyme activity follow-up. As to the total $\mathrm{T}_{3}$ follow-up, 4.03-fold increase of its concentration was detected at $24 \mathrm{~h}(P<0.01)$, whereas at $72 \mathrm{~h}$ its concentration dropped to the initial level. Free $\mathrm{T}_{3}$ concentration was 4.73 -fold increased after $24 \mathrm{~h}(P<0.001)$ and it dropped to the initial level within further hours, as well.

\section{Discussion}

The liver is one of the main organs used for studying the effects of thyroid hormones. These hormones exert a wide variety of biological actions. Thyroid hormones play a fundamental role in regulating mammalian growth and energy metabolism (Červinková et al. 1998).

In our study we measured serum concentrations of total and free $\mathrm{T}_{3}$ in $\mathrm{T}_{3}$-treated groups of rats and in the control group. To design the optimal time intervals for measuring the UCP-2 expression we focused on the kinetics of these parameters and the time of maximum expression. Excessive increase of $\mathrm{tT}_{3}$ and $\mathrm{fT}_{3}$ was observed in the $3^{\text {rd }} \mathrm{h}$ after single intraperitoneal injection of $200 \mu \mathrm{g} \mathrm{T} / 3 \mathrm{~kg}$ rat body weight; then the concentrations of $\mathrm{tT}_{3}$ and 
$\mathrm{fT}_{3}$ decreased relatively quickly. However, after repeated administration of $\mathrm{T}_{3}$ only a 4-fold to 5 -fold increase of $\mathrm{tT}_{3}$ and $\mathrm{fT}_{3}$ concentrations was found. Triiodothyronine concentration was completely normalized the third day after the last hormone administration. Reduction of redundant hormone concentration results from a rapid degradation that consists of total deiodination of $\mathrm{T}_{3}$ and inactivation by deamination and decarboxylation (Kelly 2000).

We also studied the regulation of UCP-2 expression by $\mathrm{T}_{3}$. We found the maximum of UCP-2 mRNA expression (almost 2-fold increase) at $12 \mathrm{~h}$. Voci et al. (2001) proved in their study on Kupffer cells isolated from euthyroid and hyperthyroid rat livers that UCP-2 mRNA level depended on the duration of $\mathrm{T}_{3}$ treatment. The UCP-2 mRNA level was more than doubled in the acutely $\mathrm{T}_{3}$-treated rats in their experiment (i.p. injection of $25 \mu \mathrm{g} \mathrm{T} / 100 \mathrm{~g}$ body weight $48 \mathrm{~h}$ before they were sacrificed) and its level in these acutely hyperthyroid rats was significantly higher than in the chronic $\mathrm{T}_{3}$-treated rats. Some reports describe minimum or no effect of $\mathrm{T}_{3}$ on UCP-2 mRNA, but they mostly discuss the analysis of expression after several-days of $\mathrm{T}_{3}$ application (Lanni et al. 1997; Voci et al. 2001). Our experiments with repeated $T_{3}$ application documented the same results: changes of UCP-2 expression in liver cells were not significant in our experimental groups of rats.

The increase of UCP-2 mRNA in liver tissue could be explained by increased energy expenditure and metabolism that can be induced and regulated by thyroid hormones through uncoupling. Increased energy expenditure and metabolism induce an increased production of ROS that may be a signal for up-regulation of UCP-2 mRNA and protein in hepatocytes. Evidence, that $\mathrm{T}_{3}$ increases mitochondrial ROS production (Barbe et al. 2001) supports the premise that the induction of UCP-2 in liver is a physiological antioxidant defence mechanism against increased ROS production.

We also observed the enzymatic activity of mGPDH by spectrophotometry in our study. Hormonal induction of mGPDH caused almost 4-fold increase of enzyme activity in isolated mitochondria after the repeated $T_{3}$ application. Müller and Seitz (1994) measured the mRNA expression of the enzyme by PCR and determined a significant increase caused by $\mathrm{T}_{3}$. In spite of the rapid decrease of total and free $\mathrm{T}_{3}$ concentration down to the initial level, the $\mathrm{T}_{3}$ effect on $\mathrm{mGPDH}$ in the isolated mitochondria still lasts. It is probably caused by the delay in which the hormone is bound to the specific receptor, which is followed by binding of the complex to the specific DNA region and by the activation of mRNA transcription. The increase of mGPDH activity could be explained by its de novo synthesis. The increased activity of mGPDH becomes a risk factor for mitochondria because of the increased production of reactive oxygen radicals. $\mathrm{T}_{3}$ is responsible not only for mGPDH activity increase but it also increases the UCP-2 gene expression that enables to suppress ROS production. Thus this effect could contribute to protect mitochondria against oxidative stress.

\section{Acknowledgements}

This work was supported by grant MSM0021620820.

\section{References}

Barbe P, Larrouy D, Boulanger C, Chevillotte E, Viguerie N, Thalamas C, Oliva Trastoy M, Roques M, Vidal H, Langin D 2001: Triiodothyronine-mediated up-regulation of UCP2 and UCP3 mRNA expression in human skeletal muscle without coordinated induction of mitochondrial respiratory chain genes. FASEB J 15: 13-15

Chomczynski P, Sacchi N 1987: Single-step method of RNA isolation by acid guanidinium thiocyanate-phenolchloroform extraction. Anal Biochem 162: 156-159

Cortez-Pinto H, Yang SQ, Lin HZ, Costa S, Hwang CS, Lane MD, Bagby G, Diehl AM 1998: Bacterial lipopolysaccharide induces uncoupling protein-2 expression in hepatocytes by a tumor necrosis factor-alphadependent mechanism. Biochem Biophys Res Commun 251: 313-319

Červinková Z, Šimek J, Trojovská V 1984: Effect of triiodothyronine or etiroxate on DNA-synthesis in intact and regenerating liver. Physiol Bohemoslov 33: 501-506 
Červinková Z, Svátková R, Kalous M, Rauchová H, Červinka M, Drahota Z 1998: Effect of triiodothyronine administration on the recovery of liver oxidative capacity atfter partial hepatectomy. Eur Surg Res 30: 371-377

Fleury C, Sanchis D 1999: The mitochondrial uncoupling protein-2: current status. Int J Biochem Cell Biol 31: 1261-1278

Hodný Z, Kolářová P, Rossmeisl M, Horáková M, Nibbelink M, Penicaud L, Casteilla L, Kopecký J 1998: High expression of uncoupling protein 2 in foetal liver. FEBS Lett 425: 185-190

Kelly G 2000: Peripheral metabolism of thyroid hormones: a review. Altern Med Rev 5: 306-333

Lanni A, De Felice M, Lombardi A, Moreno M, Fleury C, Ricquier D, Goglia F 1997: Induction of UCP2 mRNA by thyroid hormones in rat heart. FEBS Lett 418: 171-174

Lee FY, Li Y, Zhu H, Yang S, Lin HZ, Trush M, Diehl AM 1999: Tumor necrosis factor increases mitochondrial oxidant production and induces expression of uncoupling protein-2 in the regenerating mice [correction of rat] liver. Hepatology 29: 677-687

Livak KJ, Schmittgen TD 2001: Analysis of relative gene expression data using real-time quantitative PCR and the 2(-Delta Delta C(T)) Method. Methods 25: 402-408

Müller S, Seitz HJ 1994: Cloning of a cDNA for the FAD-linked glycerol-3-phosphate dehydrogenase from rat liver and its regulation by thyroid hormones. Proc Natl Acad Sci USA 91: 10581-10585

Ricquier D, Bouillaud F 2000: The uncoupling protein homologues: UCP1, UCP2, UCP3, StUCP and AtUCP. Biochem J 345: 161-179

Saito K, Nishikawa J, Imagawa M, Nishihara T, Matsuo M 2000: Molecular evidence of complex tissue- and sex-specific mRNA expression of the rat alpha( $2 \mathrm{u})$-globulin multigene family. Biochem Biophys Res Commun 272: $337-344$

Schneider WC, Hogeboom GH 1950: Intracellular distribution of enzymes. V. Further studies on the distribution of cytochrome $\mathrm{c}$ in rat liver homogenates. J Biol Chem 183: 123-128

Voci A, Demori I, Franzi AT, Fugassa E, Goglia F, Lanni A 2001: Uncoupling protein 2 mRNA expression and respiratory parametrs in Kupffer cells isolated from euthyroid and hyperthyroid rat livers. Eur $\mathrm{J}$ Endocrinol 145: $317-322$ 